MINERALOGIA, 39, No. 3-4: 105-113 (2008)

DOI: $10.2478 / v 10002-008-0008-2$

www.Mineralogia.pl

MINERALOGICAL SOCIETY OF POLAND

Original paper

\title{
Xenotime-(Y) veins in a Neoproterozoic metamudstone (Małopolska Block, S Poland)
}

\author{
Maja STANISŁAWSKA ${ }^{1,2 *}$, Marek MICHALIK ${ }^{1}$ \\ 1 Institute of Geological Sciences, Jagiellonian University, ul. Oleandry 2a, 30-063 Kraków, Poland \\ 2 Department of Geology, Trinity College,Dublin 2,Ireland, e-mail: stanistm@tcd.ie \\ * Corresponding author
}

Received: August 02, 2007

Accepted: February 05, 2009

\begin{abstract}
First occurrence of xenotime-(Y) veins in the Neoproterozoic metamudstone, NW margin of the Małopolska Block, is reported here. The veins are $<5 \mu \mathrm{m}$ thick, inhomogeneous and of varied morphology. Their textural characteristics, exhibiting very low $\mathrm{U}$ and Th contents $(<1 \mathrm{wt} \%)$ and relatively high heavy rare earth elements (REE) contents (12-24 $\left.\mathrm{REE}_{2} \mathrm{O}_{3} \mathrm{wt} \%\right)$, suggest hydrothermal genesis, though diagenetic precursors of the veins are not excluded. The veins provide good evidence of the mobility of $Y, R E E, U$ and Th in low-temperature conditions (anchimetamorphic to greenschist facies). The observed differences in the chemical composition of the veins may indicate multiple stages of formation, possibly during several hydrothermal events that affected the area.
\end{abstract}

Key-words: xenotime-(Y) veins, hydrothermal events, diagenesis, anchimetamorphism, Małopolska Block, S Poland

\section{Introduction}

Xenotime-( $\mathrm{Y})$ is a tetragonal orthophosphate of $\mathrm{Y}$ and heavy rare earth elements that can incorporate some $\mathrm{U}$ and $\mathrm{Th}$ ( $\mathrm{Ni}$ et al. 1995). It is a widespread accessory mineral in granitoids, pegmatites, as well as low- to high-grade metamorphic rocks (Förster 1998). Recently, hydrothermal ore-related (e.g. Kositcin et al. 2003; Vielreicher et al. 2003; Vallini et al. 2005; Rasmussen et al. 2009) and diagenetic xenotime-(Y) (e.g. Rasmussen 2005), commonly occurring in siliciclastic sedimentary rocks, proved useful as a U-Pb geochronometer, tracer of fluid mobility and micro-environment indicator. Its applications are especially promising in Precambrian suits, where fossils are not preserved, and in lower temperature environments where reliable dating methods are scarce. While hydrothermal veins containing crystals of 
xenotime-(Y) appear to be quite common, few authors mention veinlets of xenotime-(Y) filling fractures in zircon grains (Kositcin et al. 2003), apatite (Rojkovič et al. 1999), pegmatitic feldspar (Michalik, Szuszkiewicz 2003) and U-Ti oxides (Rojkovič, Konečný 2005). This contribution reports the first occurrence of xenotime-(Y) veins in a Neoproterozoic metamudstone from Poland and discusses their possible genesis. Our results indicate significant $Y$ mobility in relatively low-temperature conditions. Further geochronological investigation of the veins is proposed.

\section{Geological setting}

The sample was obtained from a drill-hole Ż-78 (depth: $520.5 \mathrm{~m}$ ) in the vicinity of Myszków and Żarki (see Żaba 1999 for details), Małopolska, S Poland. This locality is situated in the NW margin of the Małopolska Block, near the Kraków-Lubliniec fault zone, which probably represents one of the major transcontinental fault zones: Hamburg-Kraków (Żaba 1999). The Neoproterozoic metasedimentary complex (Jachowicz et al. 2008), from which the sample originates, is represented by marine siliciclastic (meta)sedimentary rocks, presumably of turbiditic genesis (Buła, Żaba 2005). Studies of the degree of diagenetic alteration, based on illitization of smectite, revealed a broad transitional zone between late diagenesis and anchimetamorphism within this complex, with local phyllitization (Kowalska 2001). Steep dipping beds encountered in drill-cores from this area indicate the existence of folds (Żaba 1999). The complex was intruded by igneous rocks during the Pennsylvanian Period, thus initiating development of a unique porphyry Mo-W deposit (Harańczyk 1980; Podemski 2001).

\section{Analythical methods}

A polished thin section (sample Ż-78) was examined under a standard petrographic microscope and a field-emission scanning electron microscope (SEM), Hitachi S-4700, at the Laboratory of SEM and Microanalysis in the Institute of Geological Sciences, Jagiellonian University, Kraków, Poland. In SEM, the carbon coated sample was imaged in backscattered electron (BSE) mode at the accelerating voltage of $20 \mathrm{kV}$ with YAG detector. Identification of minerals observed in SEM was based on chemical composition determined by energy-dispersive X-ray spectrometry (EDS) using NORAN Vantage analyser. Quantification of elements content was performed using the standardless method. Powdered sample was also analysed using PHILIPS X'Pert APD X-ray diffractometer (XRD) with $\mathrm{CuK} \alpha$ radiation to obtain data related to matrix composition.

\section{Results}

A hand specimen of the metamudstone $\dot{Z}-78$ is dark green with brighter green round spots. Thin fractures (mm-scale) are filled with calcite and epidote. Lamination of the rock is clearly visible under optical microscope due to differences between laminae colours in transmitted 
light ranging from grey to brown tones. Cleavage is also evident (Fig. 1). Quartz, feldspar, muscovite and biotite grains (mainly of medium silt fraction), angular to sub-rounded, as well as subordinate apatite, titanite, rutile and zircon are dispersed in the matrix. Biotite flakes underwent chloritization and deformation; their fractured fragments were displaced, possibly during compaction or cleavage formation. Within the matrix kaolinite, illite, chlorite, Fe-(hydro)oxides, sulphides and sulphosalts were identified. Small amounts of monazite occur as detrital grains, often in clasts with titanite, and as neoformed anhedral crystals $(<10 \mu \mathrm{m}$, with very low Th and $U$ contents $<1 \mathrm{wt} \%$ ) disseminated within the clay matrix.

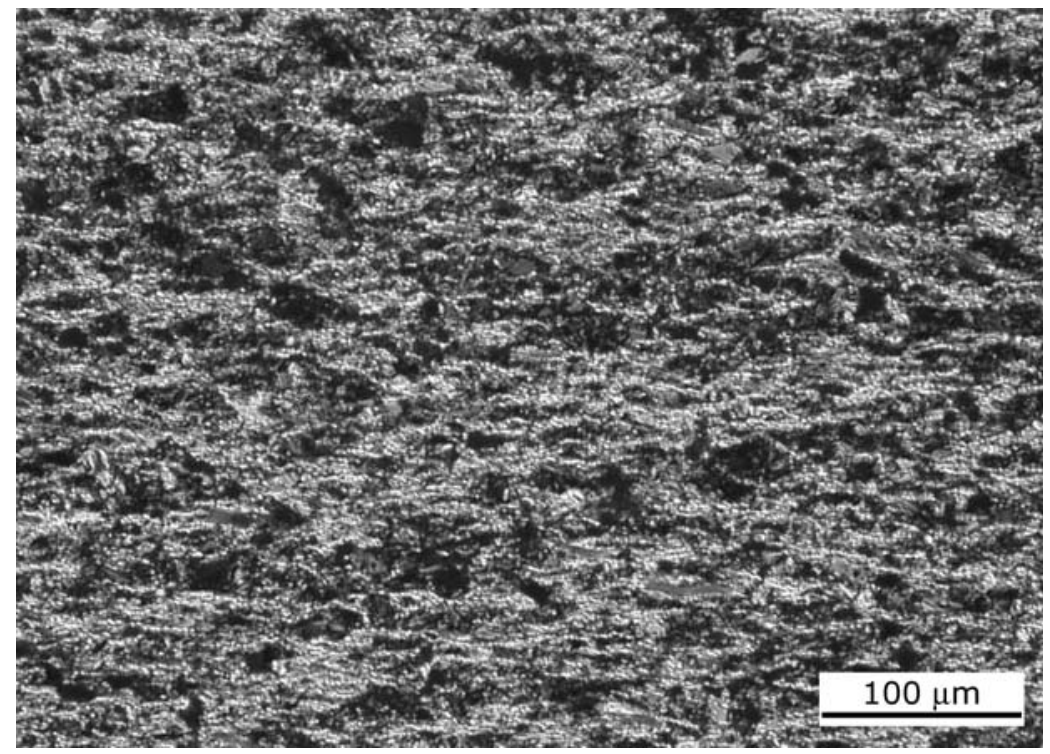

Fig. 1. Optical microscope image of metamudstone $\dot{Z}-78$ (crossed polars).

Cleavage is emphasized by kaolinite-illite-chlorite cement (grey tones) and muscovite crystals (brightest white). Quartz grains are mainly black

\subsection{Xenotime-(Y) veins}

Xenotime-(Y) veins are several $\mathrm{cm}$ long (they penetrate the whole thin section of the mudrock). Their internal structure is inhomogeneous and varied (though no zonation is observed). Some fragments comprise of a single, relatively thick layer $(<5 \mu \mathrm{m})$, whereas other bisect or split into a series of almost parallel, even thinner veinlets $(<1 \mu \mathrm{m})$. There are also ribbon-like veins, whose central regions are made of quartz and rims are xenotime-(Y) (Fig. 2).

The veins meander around various detrital grains that define their boundaries. They also penetrate the clay matrix, interleaving with chlorite-illite stacks or cutting through the phyllosilicate cement (Fig. 3). In several cases the veins are connected with xenotime-(Y) grains (Fig. 4). 


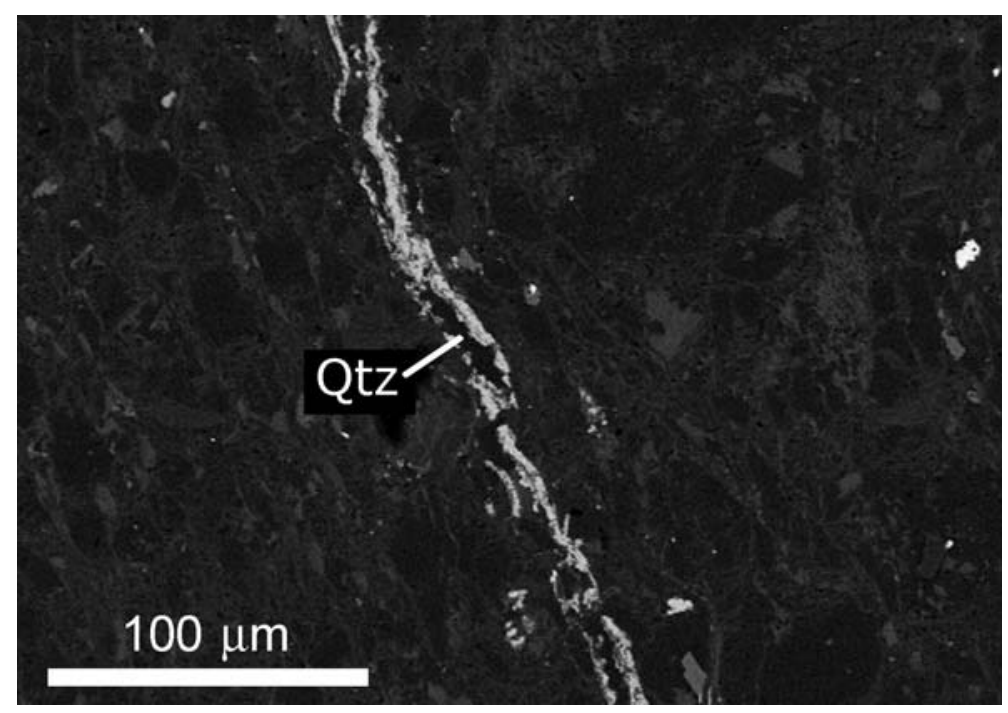

Fig. 2. SEM-BSE image of a xenotime-(Y) vein (white) with quartz (dark grey) in its central part. Qtz - quartz

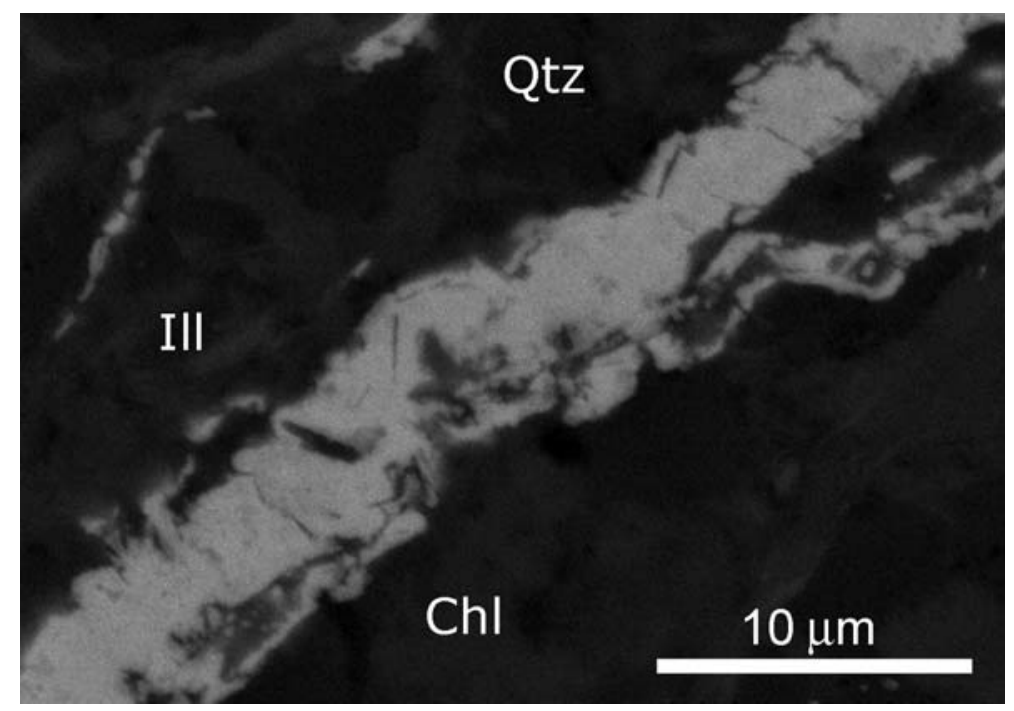

Fig. 3. SEM-BSE image of a bisecting xenotime-(Y) vein (white) with quartz (dark grey) inclusions The vein intersects illite-chlorite matrix (medium grey). Chl - chlorite, Ill - illite, Qtz - quartz

Xenotime-( $(\mathrm{Y})$ in the veins has a varied chemical composition, containing $18.8-38.0 \mathrm{wt} \%$ $\mathrm{P}_{2} \mathrm{O}_{5}, 18.6-45.3 \mathrm{wt} \% \mathrm{Y}_{2} \mathrm{O}_{3}$, and 12.3-24.0 wt $\% \mathrm{REE}_{2} \mathrm{O}_{3}$. Among REE, Dy dominates (4.5-10.8 wt\% $\left.\mathrm{Dy}_{2} \mathrm{O}_{3}\right)$, with lesser amounts of $\mathrm{Er}, \mathrm{Gd}, \mathrm{Ho}, \mathrm{Yb}, \mathrm{Lu}$ and $\mathrm{Tm}\left(\mathrm{Er}_{2} \mathrm{O}_{3}\right.$ from 3.3-5.7 $\mathrm{wt} \% ; \mathrm{Gd}_{2} \mathrm{O}_{3}$ from $1.0-4.0 \mathrm{wt} \% ; \mathrm{Ho}_{2} \mathrm{O}_{3}, \mathrm{Yb}_{2} \mathrm{O}_{3}, \mathrm{Tm}_{2} \mathrm{O}_{3}$ and $\mathrm{Lu}_{2} \mathrm{O}_{3}$ from values below detection limits to $3.3 \mathrm{wt} \%, 3.4 \mathrm{wt} \%, 1.2 \mathrm{wt} \%, 3.0 \mathrm{wt} \%$, respectively). High, variable contents of Si were noted in all analytical spots (3.3-24.1 $\mathrm{wt} \% \mathrm{SiO}_{2}$ ). Other detected elements, including: $\mathrm{Mg}$, $\mathrm{Ti}$, $\mathrm{Fe}, \mathrm{Al}, \mathrm{K}, \mathrm{Na}$, As and $\mathrm{Ca}$, contribute for the remaining $0.9-27.6 \mathrm{wt} \%$. Normalised to chondrite 


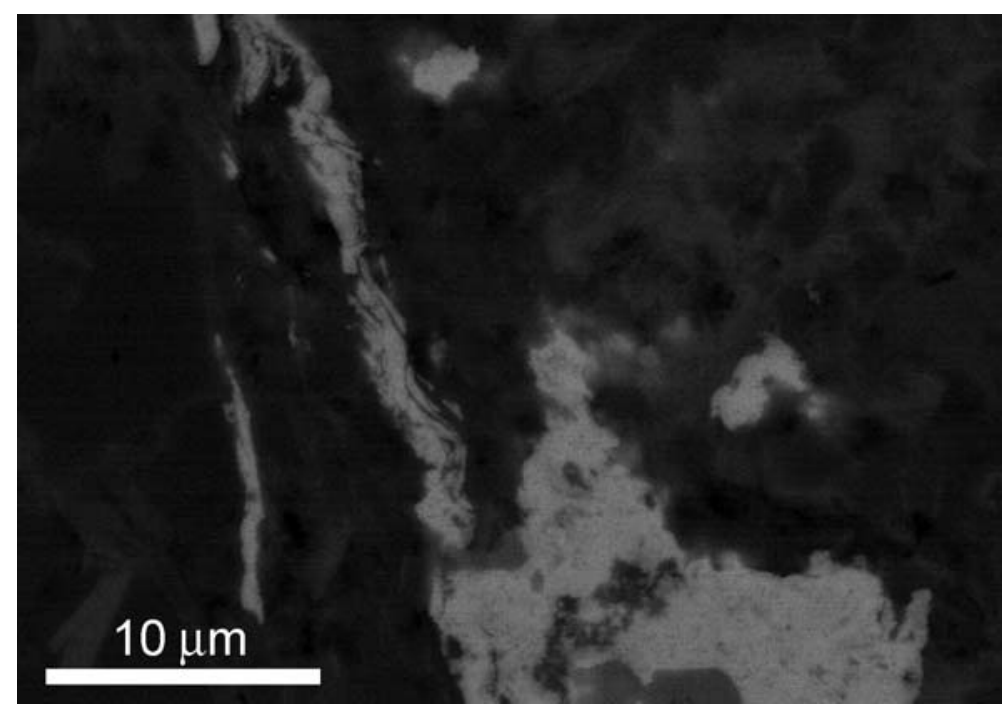

Fig. 4. SEM-BSE image of a xenotime-(Y) vein (white) connected with an anhedral xenotime-(Y) crystal (bottom right) showing numerous dissolution holes. The vein interleaves with phyllosilicate matrix (medium grey)

C1 (McDonough, Frey 1989), the REE would give a flat diagram, with no obvious anomalies. $\mathrm{U}$ and $\mathrm{Th}$ contents are below detection limit $(0.1 \mathrm{wt} \%)$.

Based on the X-ray maps of elemental distributions (Fig. 5) in the veinlet and its surroundings, $\mathrm{P}$ and $\mathrm{Y}$ are clearly concentrated inside the vein. Gd, Er, $\mathrm{Yb}$ and As correlate with the vein but are also dispersed in its surroundings. Si and K concentrate only outside the vein.

\subsection{Xenotime-(Y) crystals}

Xenotime-(Y) occurs in the sample as anhedral crystals and in veins. Single xenotime-(Y) crystals are up to $18 \mu \mathrm{m}$ in diameter and inclusions-rich. They resemble the hydrothermal xenotimes described by Kositcin et al. (2003) in being very low in $U$ and $\mathrm{Th}(<1 \mathrm{wt} \%)$ as well as having irregular boundaries and dissolution holes. The volume of xenotime-(Y) in veins predominates over the total volume of single xenotime-(Y) crystals in this rock. Only one anhedral xenotime-( $\mathrm{Y})$ crystal enriched in $\mathrm{U}\left(1.8 \mathrm{wt} \% \mathrm{UO}_{2}\right)$ was identified.

\section{Discussion and interpretation}

\subsection{Chemical composition and stoichiometric relations}

The structural formula of xenotime-(Y) can be presented as $A X \mathrm{O}_{4}$, where $A=\mathrm{Y}, \mathrm{REE}, \mathrm{U}, \mathrm{Th}$, $\mathrm{Pb}, \mathrm{Ca}$ and $X$ is mainly $\mathrm{P}$ (minor substitutions of Si, As, S are known; e.g. Ondrejka et al. 2007). In the xenotime-(Y) veins, an excess of cations in the structural position $A$ was noted. The presence of $\mathrm{Al}, \mathrm{Mg}, \mathrm{Ti}, \mathrm{Fe}, \mathrm{K}, \mathrm{Na}$ is interpreted as the result of interference with background (chiefly phyllosilicate matrix), due to the $\mu$ m-range dimensions of the veins. Janots et al. (2006) 

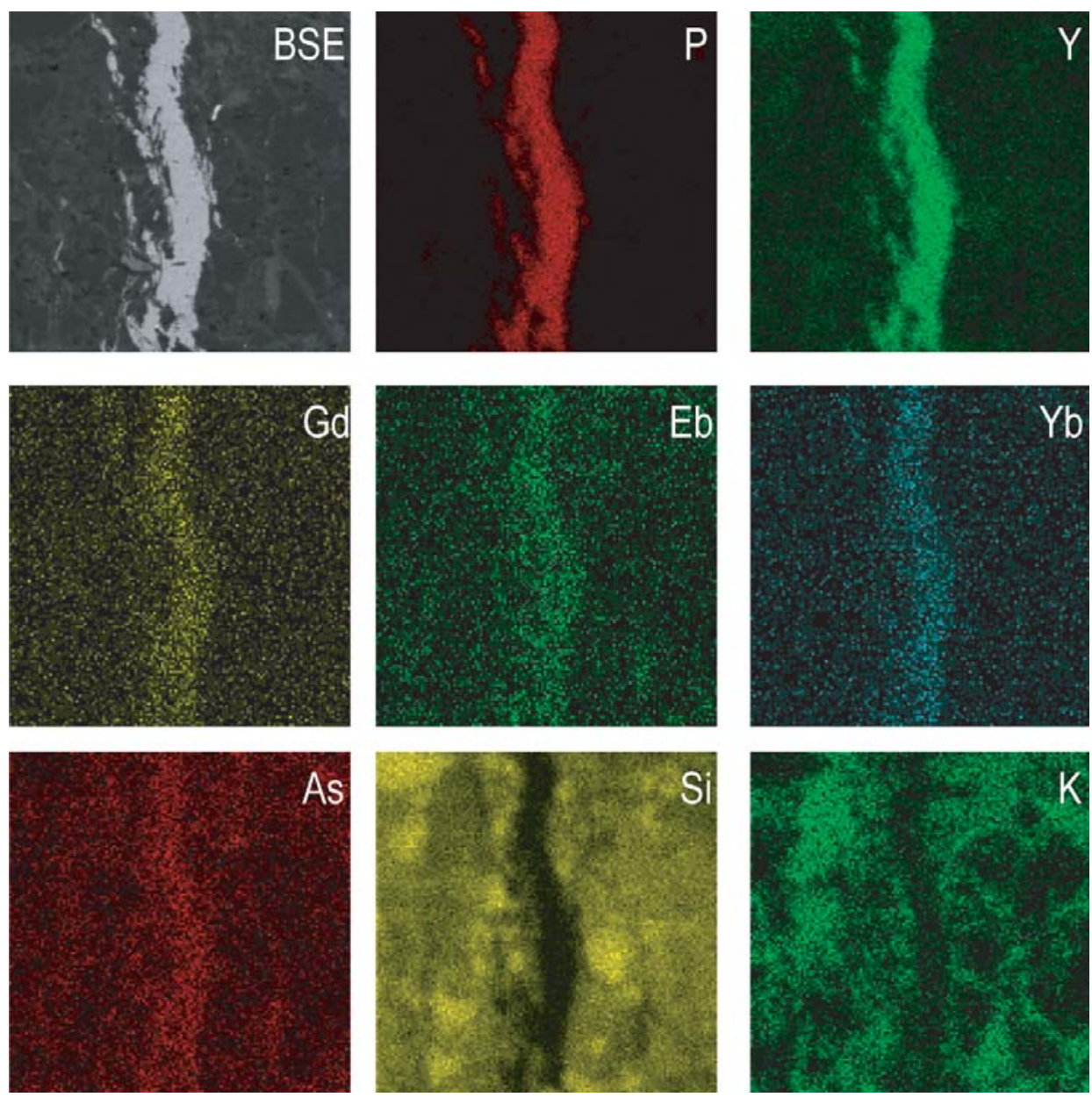

Fig. 5. BSE image and X-ray maps of $\mathrm{P}(\mathrm{K}), \mathrm{Y}(\mathrm{L}), \mathrm{Gd}(\mathrm{L}), \mathrm{Er}(\mathrm{L}), \mathrm{Yb}(\mathrm{L}), \mathrm{As}(\mathrm{L}), \mathrm{Si}(\mathrm{K})$

and $\mathrm{K}(\mathrm{K})$ in the veinlet and its surroundings. $\mathrm{P}$ and $\mathrm{Y}$ are concentrated in the vein; $\mathrm{Gd}, \mathrm{Er}, \mathrm{Yb}$ and As correlate with the vein but are also dispersed in its surroundings; $\mathrm{Si}$ and $\mathrm{K}$ concentrate outside the vein

encountered a similar problem; however, they concluded that the neighbouring minerals do not affect ratios of REE in xenotime-(Y).

Due to the standardless method used, it was impossible to infer water content (on the basis of difference between $100 \mathrm{wt} \%$ and the total content of oxides). Thus, the possible existence of hydrous analogues of xenotime-(Y) cannot be excluded.

\subsection{The origin of xenotime- $(Y)$ veins and the mobility of $Y$}

It has been suggested that different forms and chemical compositions of xenotime-(Y), in particular Y, REE and U and Th contents, reflect different genesis (Kositcin et al. 2003). Veins and fracture fillings within detrital zircon grains are typical occurrences of hydrothermal xenotime-(Y) $(i b$.$) . The reported xenotime- (\mathrm{Y})$ veins from the Małopolska Block, embedded 
in a matrix of phyllosilicates and quartz, with their distinctive chemistry (very low $\mathrm{U}$ and Th, and relatively high REE contents), possess - in our opinion - such hydrothermal characteristics. The ribbon-like fragment of the vein, with xenotime-(Y) rims and quartz centre (Fig. 2), resembles simple hydrothermal vein assemblages.

In this study, we suggest that early diagenetic and later hydrothermal fluids dissolved most of the detrital minerals containing Y, REE, U, Th, and P (e.g. apatite, monazite, xenotime-(Y), allanite) from the studied rock. An additional portion of $\mathrm{P}$ could have been introduced to pore waters during organic matter decomposition and K-feldspar dissolution. A similar scenario was proposed by Rasmussen (1996). The released elements were then transported over unknown distances, using networks of diagenetic and/or tectonic fractures, as well as between chlorite-illite stacks. An abrupt change in parameters of the environment (such as $\mathrm{pH}$, temperature or pressure) and/or chemical budget of the fluid, initiated precipitation of the xenotime-(Y) material in the form of vein fillings. The fairly immobile $\mathrm{Y}$ and REE, however, probably constituted a more localized source, migrating over few to several hundreds of microns (Wilby et al. 2007 and references therein), thus contributing to the varied REE contents of the xenotime-(Y) veins, observed in the thin-section scale.

It is possible that some precursor phases containing $\mathrm{P}, \mathrm{Y}$ and REE precipitated shortly after sediment burial within the zone of sulphate reduction and methanogenesis (Rasmussen 1996). Early diagenetic xenotime-(Y) is known as pyramidal overgrowths on detrital zircon grains mostly in sandstones but also in conglomerates, shales, siltstones and phosphorites (e.g. Rasmussen 2005 and references therein). However, such euhedral xenotime-(Y) overgrowths have not been noted in the studied thin section. Later complete dissolution of the precursor diagenetic phases by hydrothermal fluids is one of the proposed stages in the evolution of this metamudstone.

Various chemical compositions of the reported xenotime-(Y) veins can be interpreted as the evidence of several hydrothermal events. The main fault zone in the vicinity of the studied rock, which was active from the Neoproterozoic times (Buła, Żaba 2005), could have facilitated the migration of the fluids. The Mo-W porphyry ore body in Myszków area is known to be deposited in at least five hydrothermal stages (Podemski 2001); each of them may have stimulated transport of $\mathrm{Y}, \mathrm{REE}$ and $\mathrm{P}$ in fluids.

As mentioned before, xenotime-(Y) crystals joined with the veins were found (Fig. 4). One of these crystals is enriched in $\mathrm{U}\left(1.8 \mathrm{wt} \% \mathrm{UO}_{2}\right)$, which distinguishes it from the lower-U, presumably hydrothermal, xenotime-(Y) occurrences in the studied thin section. Similar concentrations of $\mathrm{U}$ in diagenetic xenotime-(Y) were reported by Kositcin et al. (2003). The lack of textural relation with zircon crystals questions (or even excludes) diagenetic origin of this crystal, whereas other features, such as irregular boundaries of the crystal and numerous dissolution holes, seem to support its hydrothermal origin. Spatial connections with the veins indicate that the two single xenotime-(Y) crystals may be anhedral precipitates of one of the hydrothermal fluid, which have encountered and dissolved their detrital precursors, so that their chemical compositions only insignificantly differ from the surrounding veins.

\subsection{A potential geochronometer}

Hydrothermal xenotime-(Y) represents a potentially useful geochronometer (e.g. Rasmussen 2005). Recent U-Pb dating of hydrothermal xenotime-(Y) in Pyrenean shear-hosted ore bodies 
constrained the age, as well as the duration of the mineralization (Schärer et al. 1999). Vallini et al. (2005) placed timeframes for events from sedimentation, through hydrothermal alteration, up to peak metamorphism of a Paleoproterozoic metasedimentary sequence in SW Australia. The xenotime-(Y) geochronometer is especially useful in non-fossilliferous complexes where dating may be problematic.

In our opinion, the reported xenotime-(Y) veins might allow for interesting age determinations of hydrothermal events that affected this Neoproterozoic complex and resulted in Mo-W mineralization (Podemski 2001). Due to the small dimensions of the veins, state-of-the-art in situ analytical techniques would be required. Two possible approaches include isotopic dating by sensitive high-resolution ion microprobe (SHRIMP II; Rasmussen et al. 2009) and electron microprobe chemical dating using the most recent protocols (Hetherington et al. 2008).

\section{Conclusions}

The reported xenotime-(Y) veins in the metamudstone sample from the Małopolska Block are of hydrothermal origin with potentially several hydrothermal events having contributed to the growth of these veins. Precursor diagenetic precipitation of xenotime-(Y) is possible but was not evidenced. The veins provide good evidence of the mobility of $\mathrm{Y}$ in the low-temperature conditions (anchimetamorphic to greenschist facies). Some mobility of REE, U and Th is also suggested. Limited dimensions of the veins require the use of in situ analytical techniques with high spatial resolution. Further geochronological investigations are proposed that can potentially resolve timing of precipitation of these veins and associated mineralization, as well as give the minimum radiogenic age of sedimentation.

Acknowledgments. This research reports a part of M.Sc. study by the first author, and was funded by an internal research project grant of the Institute of Geological Sciences, Jagiellonian University. K. Jacher-Śliwczyńska kindly provided sample Ż-78. A. Łatkiewicz, M. Skiba, W. Szeliga, and B. Zych-Habel are gratefully acknowledged for their technical assistance with SEM and XRD analyses. The paper has been greatly improved by the critical and constructive comments of two anonymous reviewers and careful language corrections made by $\mathrm{K}$. Craven.

\section{References}

BUŁA Z., ŻABA J., 2005: Pozycja tektoniczna Górnośląskiego Zagłębia Węglowego na tle prekambryjskiego i dolnopaleozoicznego podłoża. Proceedings of the $76^{\text {th }}$ Polish Geological Society Symposium, 14-42. Ruda, Poland (in Polish with English abstract).

FÖRSTER, H.-J., 1998: The chemical composition of REE-Y-Th-U-rich accessory minerals in peraluminous granites of the Erzgebirge_Fichtelgebirge region, Germany. Part II: Xenotime. American Mineralogist 83, 1302-1315.

HARAŃCZYK C., 1980: Palaeozoic porphyry copper deposits in Poland. Special Publication of the Society for Geology Applied to Mineral Deposits 1, 89-95.

HETHERINGTON C.J., JERCINOVIC M.J., WILLIAMS M.L., MAHAN K., 2008: Understanding geologic processes with xenotime: Composition, chronology, and a protocol for electron probe microanalysis. Chemical Geology 254, 133-147.

JACHOWICZ M., TOMAS A., TOMAS A., 2008: Neoproterozoic microflora from the anchimetamorphic rocks of Malopolska Block - foreland of the East-European Platform. Proceedings $33^{\text {rd }}$ International Geological Congress, 33 . 
JANOTS E., NEGRO F., BRUNET F., GOFFE B., ENGI M., BOUYBAOUENE M.L., 2006: Evolution of the REE mineralogy in HP-LT metapelites of the Sebtide complex, Rif, Morocco: Monazite stability and geochronology. Lithos 87, 214-234.

KOSITCIN N., McNAUGHTON N.J., GRIFFIN B.J., FLETCHER I.R., GROVES D.I., RASMUSSEN B., 2003 : Textural and geochemical discrimination between xenotime of different origin in the Archaean Witwatersrand Basin, South Africa. Geochimica et Cosmochimica Acta 67, 709-731.

KOWALSKA S., 2001: The degree of diagenesis of the Cambrian and Vendian? Rocks from the Malopolska Block. Polskie Towarzystwo Mineralogiczne - Prace Specjalne 18, 80-84.

McDONOUGH W.F. FREY F.A., 1989: Rare earth elements in upper mantle rocks. Reviews in Mineralogy and Geochemistry 21, 99-145.

MICHALIK M., SZUSZKIEWICZ A., 2003: Secondary xenotime-like mineral in a pegmatitic feldspar from Gołaszyce (Strzegom-Sobótka Granitoid Massif). Polskie Towarzystwo Mineralogiczne - Prace Specjalne 23, $132-134$.

NI Y., HUGHES J.M., MARIANO A.N., 1995: Crystal chemistry of the monazite and xenotime structures. American Mineralogist 80, 21-26.

ONDREJKA M., UHER P., PRSEK J., OZDIN D., 2007: Arsenian monazite-(Ce) and xenotime-(Y), REE arsenates and carbonates from the Tisovec-Rejkovo rhyolite, Western Carpathians, Slovakia: Composition and substitutions in the (REE,Y)XO4 system (X = P, As, Si, Nb, S). Lithos 95, 116-129.

PODEMSKI M. (ed.), 2001: Palaeozoic porphyry molybdenum-tungsten deposit in the Myszków area, southern Poland. Polish Geological Institute Special Papers 6, 1-88.

RASMUSSEN B., 1996: Early-diagenetic REE-phosphate minerals (florencite, gorceixite, crandallite, and xenotime) in marine sandstones; a major sink for oceanic phosphorus. American Journal of Science 296, 601-632.

RASMUSSEN B., 2005: Radiometric dating of sedimentary rocks: the application of diagenetic xenotime geochronology. Earth-Science Reviews 68, 197-243.

RASMUSSEN B., MUELLER A.G., FLETCHER I.R., 2009: Zirconolite and xenotime U-Pb age constraints on the emplacement of the Golden Mile Dolerite sill and gold mineralization at the Mt Charlotte mine, Eastern Goldfields Province, Yilgarn Craton, Western Australia. Contributions to Mineralogy and Petrology 157, 559-572.

ROJKOVIČ I., KONEČNÝ P., NOVOTNÝ L., PUŠKELOVÁ L., STREŠKO V., 1999: Quartz-apatite-REE vein mineralization in Early Paleozoic rocks of the Gemeric Superunit, Slovakia. Geologica Carpathica 50, $215-227$.

ROJKOVIČ I., KONEČNÝ P., 2005: Th-U-Pb dating of monazite from the Cretaceous uranium vein mineralization in the Permian rocks of the Western Carpathians. Geologica Carpathica 56, 493-502.

SCHÄRER U., DE PARSEVAL P., POLVE M., DE SAINT BLANQUAT M., 1999: Formation of the Trimouns talc-chlorite deposit (Pyrenees) from persistent hydrothermal activity between 112 and 97 Ma. Terra Nova. The European Journal of Geosciences 11, 30-37.

VALLINI D.A., RASMUSSEN B., KRAPEZ B., FLETCHER I.R., McNAUGHTON N.J., 2005: Microtextures, geochemistry and geochronology of authigenic xenotime: constraining the cementation history of a Palaeoproterozoic metasedimentary sequence. Sedimentology 52, 101-122.

VIELREICHER N.M., GROVES D.I., FLETCHER I.R., McNAUGHTON N.J., RASMUSSEN B., 2003: Hydrothermal Monazite and Xenotime Geochronology: A New Direction for Precise Dating of Orogenic Gold Mineralization. Society of Economic Geologists Newsletter 53, 1-16.

WILBY P.R., PAGE A.A., ZALASIEWICZ J.A., MILODOWSKI A.E., WILLIAMS M., EVANS J.A., 2007: Syntectonic monazite in low-grade mudrocks; a potential geochronometer for cleavage formation? Journal of the Geological Society of London 164, 53-56.

ŻABA J., 1999: Ewolucja strukturalna utworów dolnopaleozoicznych w strefie granicznej bloków górnośląskiego i małopolskiego. Prace Państwowego Instytutu Geologicznego 166, 5-162 (in Polish with English abstract). 